\title{
Antifungal, antiradical and cytotoxic activities of extractives obtained from Tagetes patula L. (Asteraceae), a potential acaricide plant species
}

\author{
Flávio A.S. Politi, Geisiany M. Queiroz-Fernandes, Edvânio R. Rodrigues, Jolindo A. Freitas, \\ Rosemeire C.L.R. Pietro*
}

School of Pharmaceutical Sciences of Araraquara, Department of Drugs and Medicines, Univ. Estadual Paulista, UNESP, Rodovia Araraquara-Jaú, km 01, CEP 14801 902, Araraquara, SP, Brazil

\section{A R T I C L E I N F O}

\section{Article history:}

Received 24 September 2015

Received in revised form

24 February 2016

Accepted 26 February 2016

Available online 2 March 2016

\section{Keywords:}

Entomopathogenic fungi

Dermatophytes

Antioxidant

Cytotoxicity

Plant extracts

Tagetes patula

\begin{abstract}
A B S T R A C T
Tagetes patula L. shows a complex chemical composition, ranging from glycosylated flavonoids and thiophenes in extracts until terpenoids in the essential oil. In the present study, due to this rich flavonoidic constitution, its antioxidant potential was determined, having shown values of antiradical percentage superior to reference compounds, mainly the extracts prepared with flowers. Previous studies performed emphasized the acaricide potential of T. patula and thus, the present study aimed to verify the action of extractives obtained from aerial parts on growth of entomopathogenic fungi related to biological control of brown dog tick Rhipicephalus sanguineus and the action against pathogenic fungi closely associated with pets. None of the samples inhibited the growth of strains of Beauveria bassiana or Metarhizium anisopliae, enabling feasible future studies of synergism on acaricide activity of formulations containing fungi and extracts. The antimicrobial activity of ethanolic extract of flowers ( $\left.\mathrm{Fl}_{\mathrm{EtOH}} \mathrm{H} \%\right)$ against Microsporum canis and Trichophyton rubrum was significant $(193.3 \mu \mathrm{g} / \mathrm{mL}$ and $253.9 \mu \mathrm{g} / \mathrm{mL}$, respectively), as well as ethanolic extract from aerial parts ( $\left.\mathrm{AP}_{\text {EtOH70\% }}\right)$ against $T$. rubrum $(312.5 \mu \mathrm{g} / \mathrm{mL})$. In order to ensure the safety of a topical formulation containing the extractives of $T$. patula, the cytotoxic potential of these samples were tested in murine macrophages cells. At higher concentrations all extracts were quite lethal, with $\mathrm{IC}_{50}$ ranging from $210.96 \mu \mathrm{g} / \mathrm{mL}$ to $468.75 \mu \mathrm{g} / \mathrm{mL}$ for $\mathrm{AP}_{\mathrm{EtOH} 70 \%}$ and $\mathrm{Fl}_{\mathrm{EtOH}}$ \% , respectively. These results suggest that the application of a product containing $T$. patula extractives in the control of ticks could be used, at principle, only on the environment.
\end{abstract}

(C) 2016 Elsevier Ltd. All rights reserved.

\section{Introduction}

Researches about the use of plant species in the control of animal parasites are scarce, with a lack of further information regarding the conditions of production, harvest time, plant parts and quantities used in the elaboration of products [1]. The use of plants, either as phytotherapics or a source of prototype substances, shows the importance of scientific research for the development of a new drug. Among the advantages of herbal medicines that justify their use are synergistic effects of its components, the combination of mechanisms for compounds acting on different molecular targets, lower risk of side effects and less costs in research [2].

\footnotetext{
* Corresponding author.

E-mail addresses: flaviopoliti@hotmail.com (F.A.S. Politi), geisyq@hotmail.com (G.M. Queiroz-Fernandes), edvaniorodrigues@uol.com.br (E.R. Rodrigues), jolindoo@yahoo.com.br (J.A. Freitas), pietrorc@fcfar.unesp.br (R.C.L.R. Pietro).
}

Tagetes patula L. (Asteraceae), popularly known as dwarf marigold or French marigold is an annual plant, 20-30 cm height, native to North America and widely disseminated throughout the world. The genus Tagetes has many biological activities reported against many organisms such as fungi [3-5], Gram positive and Gram negative bacteria [6-8], virus [9], nematodes [10,11], insects [12-14], ticks [15-18] and others. The phytochemical investigation of different parts of $T$. patula has resulted in the isolation of several chemical constituents of different classes of secondary metabolites, such as benzofurans, carotenoids, flavonoids and thiophenes, the latter being responsible for a variety of biocides properties [19]. Bano et al. (2002) [20] isolated and characterized thiophenes, steroid and terpenoids from roots, leaves and flowers of $T$. patula. Flavonoids, such as quercetin and kaempferol were reported by Ivancheva and Zdravkova (1993) [21]. Politi et al. (2012) [16], using the same ethanolic extract applied in the tests of the present study, identified by HPLC-MS twelve $O$-glycosylated flavonoids: 
kaempferol, patuletin, quercetin-3-O-pentoside, quercetin-3-Oglucoside (isoquercitrin) and quercetin-3-O-galactoside (hyperoside), patuletin-7-O-glucoside (patulitrin) or 6-O -methyl-quercetin-3-O-glucoside, quercetin-3-O-rhamnosyl-O-xyloside, quercetin-3-O-di-rhamnoside, quercetin-3-O-glycosyl-7-O-rhamnosyl, quercetin-3-O-rhamnosyl-7-O-glycosyl, kaempferol-3-O-dihexoside and quercetin-3-O-galloyl-hexoside. In another study, by GC-MS, Politi et al. (2013) [17] identified in the essential oil of the aerial parts of $T$. patula 55 compounds, being the main, 4-vinyl guaiacol and gamma-terpinene, appearing also in good proportions limonene, (E)-tagetone and spathulenol.

Researches with entomopathogenic fungi as biological controllers have been made in order to assist the establishment of rational and effective strategies against arthropods of commercial interest or pathogenic [22]. Metarhizium anisopliae and Beauveria bassiana are the most well characterized entomopathogenic fungi. Hence, many studies describe its potential for controlling many plagues, including ticks [23-26]. The capacity of production and obtainment of formulations from the association of this fungus with different compounds makes it one of the most traded in the world [27].

Based on the phytochemistry previously described and the biocide potential of the $T$. patula reported on recent studies of antitick potential of the $70 \%$ ethanolic extract $[16,18]$ and essential oil [17] of this species against the brown dog tick Rhipicephalus sanguineus, the present investigation aimed to verify the action of these plant extractives on growth of entomopathogenic fungi directly related to the biological control of such ixodids. Besides, the investigation of the activity of these plant extractives over dermatophytes, may also contribute to eliminate pathogenic fungi closely associated with the primary host of these ticks [28]. Furthermore, based on the rich constitution of flavonoids, was analyzed the antioxidant potential of the samples. In order to verify the safe use of these extractives like a possible acaricidal formulation, in a first moment, cytotoxicity assays were conducted in macrophages cells.

\section{Material and methods}

\subsection{Plant material}

Aerial parts of $T$. patula (stems, leaves and flowers) were obtained from the Collection of Medicinal and Aromatic Plants (CPMA) of the Multidisciplinary Center for Chemical, Biological and Agricultural Research (CPQBA), Universidade Estadual de Campinas (UNICAMP). The planting was done from seeds of Top Seed Garden line $\left(\right.$ Agristar $\left.^{\circledR}\right)$. A voucher specimen was deposited in the CPQBA Herbarium (process number 1421/2013).

\subsection{Test microorganisms}

The microbiological tests were conducted with the following strains: Trichophyton rubrum (INCQS 40004 and a clinical isolate of Oswaldo Cruz Foundation - OCF), Trichophyton mentagrophytes (INCQS 40051), Microsporum canis (clinical isolate, Laboratório de Micologia Clínica, FCFAR/UNESP), M. anisopliae (ATCC 343 and a clinical isolate of Oswaldo Cruz Foundation - OCF) and B. bassiana (ATCC 507 and 4531).

\subsection{Extracts preparation}

After the stabilization and drying, the aerial parts of the plant were triturated into cutting mill. The powdered drug was used for preparing the extracts by percolation using ethanol $70 \%(\mathrm{v} / \mathrm{v})$ as solvent, with average flow rate of 40 drops/minute. After complete solvent evaporation, the dry extract was lyophilized and stored in a desiccator.

\subsection{Determination of total flavonoids content}

The total flavonoid content was estimated using a colorimetric method based on the formation of a flavonoid-aluminum complex [29]. The values were calculated from a calibration curve obtained with quercetin (95\% purity, Merk) at concentrations of $0.25,0.5,1.0$, 2.0, 4.0, 8.0 and $16.0 \mathrm{mg} / \mathrm{mL}$. Final results were expressed in milligrams per gram of quercetin equivalent $(\mathrm{QE})$, performed at $430 \mathrm{~nm}$ in a spectrophotometer Shimadzu UV-1603. The reading was done after $15 \mathrm{~min}$ of color reaction in the dark. An $80 \%$ methanolic solution (v/v) was used as blank. Samples of $70 \%$ ethanolic extract of the aerial parts $\left(\mathrm{AP}_{\mathrm{EtOH}} 7 \%\right)$ and flowers $\left(\mathrm{Fl}_{\mathrm{E}-}\right.$ toH70\%) of $T$. patula were prepared to a stock concentration of $0.5 \mathrm{mg} / \mathrm{mL}$ in $80 \% \mathrm{MeOH}$ solution (v/v). Aliquots of each stock solution were added to $2 \mathrm{~mL}$ of hexahydrate aluminum chloride solution $\mathrm{AlCl}_{3}\left(6 \mathrm{H}_{2} \mathrm{O}\right)$ in $2 \% \mathrm{MeOH}(\mathrm{v} / \mathrm{v})$, adjusting final volume to $4 \mathrm{~mL}$ in $80 \% \mathrm{MeOH}$ solution $(\mathrm{v} / \mathrm{v})$.

\subsection{Antiradical potential}

The antioxidant activity assay of extractives was based on free radical scavenging activity of the 2,2-diphenyl-1-picrylhydrazyl (DPPH) solution [30]. Gallic acid, rutin, quercetin and vitamin C were used as standards; dilutions of $\mathrm{AP}_{\mathrm{EtOH}} \mathrm{H} \%$, aerial parts without flowers (APWF $\mathrm{EtOH}_{70 \%}$ ) and $\mathrm{Fl}_{\mathrm{EtOH} 70 \%}$ were tested. Briefly, $2.5 \mathrm{~mL}$ of DPPH solution in $0.004 \% \mathrm{MeOH}$ was added to $1 \mathrm{~mL}$ of different concentrations of plant extracts. A solution in methanol $(2.5: 1, \mathrm{v} / \mathrm{v})$ was used as negative control and pure $\mathrm{MeOH}$ was the blank. The absorbance was read at $517 \mathrm{~nm}$ in spectrophotometer (Shimadzu1603). The antiradical activity was calculated as the percentage of $\mathrm{DPPH}$ discoloration, according to the equation below:

DPPH Scavenged $(\%)=\frac{\mathrm{Ac}-\mathrm{At}}{\mathrm{Ac}} \times 100$

Where: Ac = absorbance of DPPH solution (negative control); At $=$ absorbance of test sample.

\subsection{Antimicrobial activity}

The antimicrobial activity was determined by minimum inhibitory concentration (MIC) according to adapted protocols from CLSI M38-A2 [31]. Extracts were prepared in dimethylsulfoxide (DMSO) and diluted in RPMI 1640 medium to obtain a $5 \mathrm{mg} / \mathrm{mL}$ solution. Amphotericin B $(16 \mathrm{mg} / \mathrm{mL})$ was the antibiotic used as positive control for fungal strains. The inoculum was obtained by resuspending fungal cells in $0.9 \%$ saline and adjusted to obtain approximately $5 \times 10^{3} \mathrm{CFU} / \mathrm{mL}$. Briefly, $100 \mu$ of this cell suspension were applied in 96 wells cell culture plates with $100 \mu \mathrm{l}$ of medium and $100 \mu \mathrm{l}$ of the plant extracts, performing serial dilutions. The plates were incubated in an orbital shaker at $100 \mathrm{rpm}$ for 7 days at $28^{\circ} \mathrm{C}$ and then the visual reading was done. There were a negative growth control constituted by only medium, a negative extract control containing extracts and medium and a growth control containing cells and medium. The MIC was considered as the lowest concentration that inhibited fungal growth.

\subsection{Cytotoxicity assay}

Cytotoxicity assay was adapted from Ahmed et al. (1994) [32]. The murine macrophage strain J774 was maintained in RPMI medium ( $\mathrm{pH} 7$ ) supplemented with $10 \%$ fetal bovine serum, $0.2 \%$ sodium bicarbonate, $10 \mathrm{mM}$ Hepes, penicillin $(100 \mathrm{U} / \mathrm{mL})$ and 
streptomycin $(100 \mu \mathrm{g} / \mathrm{mL})$, subsequently incubated at $37{ }^{\circ} \mathrm{C}$ under $5 \% \mathrm{CO}_{2}$ atmosphere until exponential growth phase.

Stock solutions of plant extracts were prepared in DMSO, diluted with the culture medium 1:10 (v/v) and applied to the 96 wells cell culture plate, proceeding to serial dilution in a $1: 1$ ratio. The concentration range test varied from $15.625 \mathrm{mg} / \mathrm{mL}$ to $2000 \mathrm{mg} / \mathrm{mL}$. The cytotoxicity of the samples was determined by adding resazurin $(0.1 \mathrm{mg} / \mathrm{mL})$. The reading was performed on luminescence microplate reader Spectra Fluor Plus at 530 and 590 nm [33].

\subsection{Statistical analysis}

Analyses of variance (ANOVA) were performed, and the averages were compared by parametric test of Tukey ( $p<0.05)$, using the software StatPlus 2009 (Soft Analyst ${ }^{\circledR}$ ). Pearson linear correlation test $(\mathrm{p}<0.05)$ was applied to indicate the correlation coefficient between total flavonoids content and the antioxidant activity of the extracts. All the tests were executed in triplicate.

\section{Results}

Yields of $44.9 \%$ for the $\mathrm{AP}_{\mathrm{EtOH} 70 \%}, 31.9 \%$ for the $\mathrm{APWF}_{\mathrm{EtOH} 70 \%}$ and $41.2 \%$ for the $\mathrm{Fl}_{\mathrm{EtOH} 70 \%}$ were obtained in the extracts preparation. The average content of total flavonoids in the extract $\mathrm{AP}_{\mathrm{EtOH} 70 \%}$ and $\mathrm{Fl}_{\mathrm{EtOH} 70 \%}$ was approximately $7.27 \%$ and $12.45 \%$, respectively (Table 1). The analysis of variance (ANOVA) revealed that the average of total flavonoid content of aerial parts extracts and flowers extract differ significantly $(p<0.05)$. The content of flavonoids (quercetin equivalents) obtained from the extract of flowers of T. patula is almost double the flavonoid content of the extract of the aerial parts.

The $\mathrm{Fl}_{\mathrm{EtOH} 70 \%}$ presented the best antiradicalar activity (Table 2), higher than the gallic acid and quercetin standards. There were no statistically significant differences $(p<0.05)$ by analysis of variance in mean values of antioxidant activity between the samples and the standards. This results show that the hydroalcoholic extracts of T. patula have a high antiradical potential. The analysis of Pearson linear correlation $(\mathrm{p}<0.05)$ indicated a strong correlation between total flavonoids content and the respective antioxidant activity of $\mathrm{AP}_{\mathrm{EtOH} 70 \%}$ and $\mathrm{Fl}_{\mathrm{EtOH} 70 \%}(\rho=0.98$ and $\rho=0.99$, respectively).

All extracts showed good results against the T. rubrum, highlighting the best antifungal action of $\mathrm{Fl}_{\mathrm{EtOH} 70 \%}$ against OCF strain (Table 3). Against T. mentagrophytes, the most effective extracts were $\mathrm{Fl}_{\mathrm{EtOH} 70 \%}$ and $\mathrm{AP}_{\mathrm{EtOH} 70 \%}$, with no statistically significant difference between them $(p<0.05)$. Significant results against $M$. canis were exhibited by all extracts, emphasizing the action of $\mathrm{Fl}_{\mathrm{EtOH} 70 \%}$, the lowest inhibitory concentration of all extract tested. The entomopathogenic fungi, was not sensitive to extracts showing MIC values only at the highest inhibitory concentration applied

Table 1

Spectrophotometric quantification $(430 \mathrm{~nm})$ of the total flavonoids (equivalent in quercetin) present in the dried extract of $T$. patula.

\begin{tabular}{lll}
\hline $\mathrm{C}(\mu \mathrm{g} / \mathrm{mL})$ & $\mathrm{FC}(\mathrm{mgEQ} / \mathrm{g})$ & \\
\cline { 2 - 3 } & $\mathrm{AP}_{\text {EtOH70\% }( \pm \mathrm{SD})}$ & $\mathrm{Fl}_{\text {EtoH70\% }}( \pm \mathrm{SD})$ \\
\hline 125.0 & $73.06^{\mathrm{a}}( \pm 0.5351)$ & $123.95^{\mathrm{b}}( \pm 1.0480)$ \\
156.25 & $71.98^{\mathrm{a}}( \pm 0.9612)$ & $121.90^{\mathrm{b}}( \pm 2.4881)$ \\
187.5 & $72.88^{\mathrm{a}}( \pm 1.6569)$ & $126.78^{\mathrm{b}}( \pm 0.7272)$ \\
250.0 & $73.03^{\mathrm{a}}( \pm 0.6638)$ & $125.75^{\mathrm{b}}( \pm 2.6054)$ \\
Mean & $72.74^{\mathrm{a}}( \pm 0.5012)$ & $124.59^{\mathrm{b}}( \pm 0.9680)$ \\
\hline
\end{tabular}

C: sample concentration; $\mathrm{AP}_{\mathrm{EtOH} 70 \%}$ : 70\% ethanolic extract from aerial parts of T. patula; $\mathrm{Fl}_{\mathrm{EtOH} 70 \%}$ : 70\% ethanolic extract from flowers of T. patula; FC: flavonoids content, calculated as milligrams of quercetin equivalents per gram of dry extract (mgEQ/g); SD: standard deviation. Values with the same superscript letters within a column do not showed statistically significant differences by Tukey test $(\mathrm{p}<0.05)$.
Table 2

Antiradicalar activity of patterns and ethanolic extracts of $T$. patula by DPPH method.

\begin{tabular}{lll}
\hline Sample & Absorbance $( \pm$ SD $)$ & Antiradicalar Activity \% $( \pm$ SD $)$ \\
\hline Gallic Acid & $0.0408( \pm 0.0023)$ & $93.154^{\mathrm{a}}( \pm 0.386)$ \\
Rutin & $0.0532( \pm 0.0009)$ & $91.075^{\mathrm{a}}( \pm 0.157)$ \\
Quercetin & $0.0457( \pm 0.0020)$ & $92.327^{\mathrm{a}}( \pm 0.339)$ \\
Vitamin C & $0.0232( \pm 0.0010)$ & $96.105^{\mathrm{a}}( \pm 0.173)$ \\
$\mathrm{AP}_{\text {EtOH70\% }}$ & $0.0563( \pm 0.0014)$ & $90.556^{\mathrm{a}}( \pm 0.243)$ \\
$\mathrm{APWF}_{\text {EtOH70\% }}$ & $0.0593( \pm 0.0010)$ & $90.047^{\mathrm{a}}( \pm 0.171)$ \\
$\mathrm{Fl}_{\text {EtOH70\% }}$ & $0.0396( \pm 0.0017)$ & $93.350^{\mathrm{a}}( \pm 0.285)$ \\
\hline
\end{tabular}

DPPH: 2,2-diphenyl-1-picrylhydrazyl; $\mathrm{AP}_{\mathrm{EtOH}} \%$ : 70\% ethanolic extract from aerial parts of T. patula; $\mathrm{APWF}_{\mathrm{EtOH} 70 \%}$ : 70\% ethanolic extract from aerial parts without flowers of T. patula; $\mathrm{Fl}_{\mathrm{EtOH} 70 \%}$ : 70\% ethanolic extract from flowers of T. patula. Values with the same superscript letters within a column do not showed statistically significant differences by Tukey test $(\mathrm{p}<0.05)$.

Table 3

Minimum inhibitory concentration (MIC) values of different extracts of T. patula against dermatophytes and entomopathogenic fungi.

\begin{tabular}{lllll}
\hline \multirow{2}{*}{ Microorganisms } & \multicolumn{3}{l}{$\mathrm{MIC}(\mu \mathrm{g} / \mathrm{mL})$} & \\
\cline { 2 - 5 } & $\mathrm{AP}_{\mathrm{EtOH} 70 \%}$ & $\mathrm{APWF}_{\mathrm{EtOH}} \%$ & $\mathrm{Fl}_{\mathrm{EtOH} 70 \%}$ & Ampho B \\
\hline T. rubrum (40004) & $312.50^{\mathrm{A}, \mathrm{a}}$ & $625.00^{\mathrm{A}, \mathrm{b}}$ & $410.15^{\mathrm{A}, \mathrm{a}}$ & $2.0^{\mathrm{A}, \mathrm{c}}$ \\
T. rubrum (OCF) & $468.75^{\mathrm{B}, \mathrm{a}}$ & $937.50^{\mathrm{B}, \mathrm{b}}$ & $253.90^{\mathrm{B}, \mathrm{a}}$ & $2.0^{\mathrm{A}, \mathrm{c}}$ \\
T. mentagrophytes (40051) & $625.0^{\mathrm{C}, \mathrm{a}}$ & $1041.66^{\mathrm{B}, \mathrm{b}}$ & $572.91^{\mathrm{A}, \mathrm{a}}$ & $4.8^{\mathrm{B}, \mathrm{c}}$ \\
M. canis (CI) & $703.13^{\mathrm{C}, \mathrm{a}}$ & $703.13^{\mathrm{A}, \mathrm{a}}$ & $195.31^{\mathrm{B}, \mathrm{b}}$ & $4.0^{\mathrm{B}, \mathrm{c}}$ \\
M. anisopliae (343) & $1250.0^{\mathrm{D}, \mathrm{a}}$ & $1250.0^{\mathrm{C}, \mathrm{a}}$ & $1250.0^{\mathrm{C}, \mathrm{a}}$ & $16.0^{\mathrm{C}, \mathrm{b}}$ \\
M. anisopliae (OCF) & $1250.0^{\mathrm{D}, \mathrm{a}}$ & $625.0^{\mathrm{A}, \mathrm{b}}$ & $1250.0^{\mathrm{C}, \mathrm{a}}$ & $16.0^{\mathrm{C}, \mathrm{c}}$ \\
B. bassiana (507) & $1250.0^{\mathrm{D}, \mathrm{a}}$ & $1250.0^{\mathrm{C}, \mathrm{a}}$ & $1041.66^{\mathrm{C}, \mathrm{a}}$ & $8.0^{\mathrm{D}, \mathrm{b}}$ \\
B. bassiana (4531) & $1250.0^{\mathrm{D}, \mathrm{a}}$ & $625.0^{\mathrm{A}, \mathrm{b}}$ & $1250.0^{\mathrm{C}, \mathrm{a}}$ & $8.0^{\mathrm{D}, \mathrm{c}}$ \\
\hline
\end{tabular}

CI: clinical isolate; $\mathrm{AP}_{\mathrm{EtOH} 70 \%}$ : 70\% ethanolic extract from aerial parts of T. patula; $\mathrm{APWF}_{\mathrm{EtOH} 70 \%}$ : 70\% ethanolic extract from aerial parts without flowers of T. patula; $\mathrm{Fl}_{\mathrm{EtOH} 70 \%}$ : 70\% ethanolic extract from flowers of T. patula; Ampho B: amphotericin B. Superscript case letters refer to comparisons within the same column; Superscript lower case letters refer to comparisons within the same row. Values followed by the same letter do not show statistically significant differences by Tukey test ( $\mathrm{p}<0.05$ ).

(Table 3). Considering that these microorganisms represent an efficient biological control of ticks, it was satisfactory that the extracts tested presented a low activity against them, thus preserving its acaricidal potential.

All extracts were highly cytotoxic, eliminating almost $100 \%$ of the macrophage cells, especially the $\mathrm{AP}_{\mathrm{EtOH} 70 \%}$ (96.24\% cell lysis) (Fig. 1). The concentrations that destroy $50 \%$ of macrophages ( $\mathrm{IC}_{50}$ ) varied from $\mathrm{IC}_{50}=210.93 \mu \mathrm{g} / \mathrm{mL}$, for the $\mathrm{AP}_{\mathrm{EtOH} 70 \% \text {, to }}$ $\mathrm{IC}_{50}=468.75 \mu \mathrm{g} / \mathrm{mL}$, for $\mathrm{Fl}_{\mathrm{EtOH} 70 \%}$ (Table 4). The $\mathrm{IC}_{50}$ values of the $\mathrm{AP}_{\mathrm{EtOH} 70 \%}$ and $\mathrm{APWF}_{\mathrm{EtOH} 70 \%}$ showed no statistically significant differences between them $(\mathrm{p}<0.05)$.

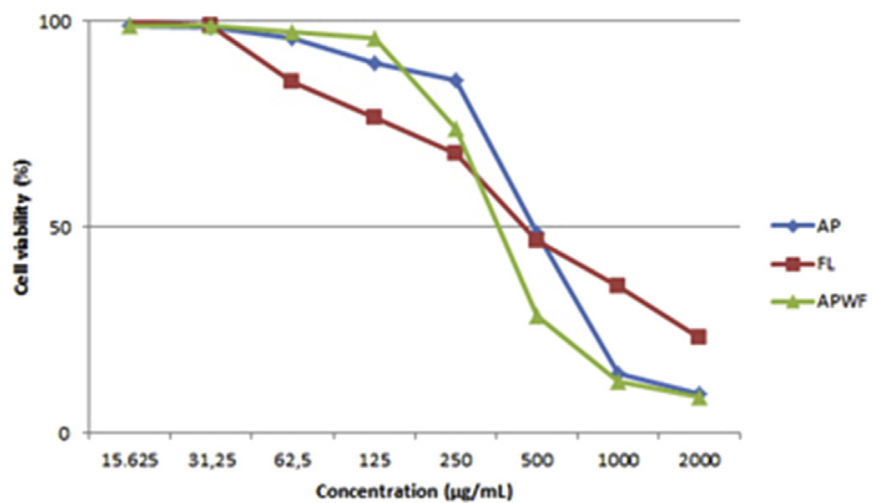

Fig. 1. Cell viability of murine macrophage front of ethanolic extracts of $T$. patula. 
Table 4

$\mathrm{IC}_{50}(\mu \mathrm{g} / \mathrm{mL})$ of $70 \%$ ethanolic extracts of $T$. patula front of J774 macrophage cells.

\begin{tabular}{lr}
\hline Sample & $\mathrm{IC}_{50}(\mu \mathrm{g} / \mathrm{mL}) \pm \mathrm{SD}$ \\
\hline $\mathrm{AP}_{\text {EtOH }}$ & $210.93^{\mathrm{a}}( \pm 11.04)$ \\
$\mathrm{APWF}_{\text {EtOH }}$ & $375.0^{\mathrm{a}}( \pm 35.35)$ \\
$\mathrm{Fl}_{\text {EtOH }}$ & $468.75^{\mathrm{b}}( \pm 44.19)$ \\
\hline
\end{tabular}

SD: standard deviation; $\mathrm{AP}_{\mathrm{EtOH}}: 70 \%$ ethanolic extract from aerial parts of T. patula; $\mathrm{Fl}_{\mathrm{EtOH}}$ : $70 \%$ ethanolic extract from aerial parts of T. patula; $\mathrm{APWF}_{\mathrm{EtOH}}: 70 \%$ ethanolic extract from aerial parts without flowers of $T$. patula. Values followed by the same letter do not show statistically significant differences by Tukey test $(\mathrm{p}<0.05)$.

\section{Discussion}

During the last decades, the health professionals interest have been directed to natural therapies based on phytotherapics, not only in developing countries but also in global economic powers, which has attracted the attention of multinational pharmaceutical companies, encouraging the investment of millions of dollars in this research area. However, despite this expansion, there is still much to be done regarding to standardization, regularization and confirmation of the pharmacological activities of the great majority of natural products marketed.

Because the preponderant presence of flavonoids in the extract of $T$. patula, the quantifying of this important class of secondary metabolites was performed in this study, using a colorimetric assay of complexation of aluminum chloride with flavonoid nucleus of the compounds present in the sample [34]. This assay is accurate and reproducible method, providing very small or no deviations between a test and another with the same samples. In our work, the results obtained with the $70 \%$ ethanolic extract of $T$. patula are similar that found in other studies with plants of the same genus. Our results are quite superior of other plant species, for example, the value of total flavonoid content of $31.15 \mathrm{mg} \mathrm{C} / \mathrm{g}$ (milligrams of catechin per gram of dry extract) provided by Hajimahmoodi et al. (2008) [35] for Punica granatum (Punicaceae). The search for the discovery of novel antioxidants compounds with natural origin to replace synthetics such as butylhydroxyanisole (BHA) and butylated hydroxytoluene (BHT) - used for preserving the quality and safety of food, drugs and cosmetics - is a scientific hotspot [36]. This demand is due to the fact that these synthetic antioxidants have a high volatility and instability at high temperatures, which present some toxicity and because they are less potent than the natural antioxidant agents [37,38].

In the present study, analysis of variance showed that the extracts tested presented similar values of antiradical activity when compared with each other and compared to pattern compounds (gallic acid, vitamin $\mathrm{C}$, quercetin and rutin), highlighting the $\mathrm{Fl}_{\mathrm{E}-}$ tOH70\%, which showed antiradical activity higher than gallic acid, quercetin and rutin. For comparison, Li et al. (2007) [39] obtained with ethanolic extract of Tagetes erecta 93\% of antiradical activity for Xinhong cultivar, however, for other cultivars the average activity was only $75.59 \%$. The great antiradical potential presented by the extracts is related to its high content of flavonoids. It is generally assumed that the antioxidant or antiradical maximum activity of flavonoids is mainly due to the occurrence of the 2, 3 double bond in combination with the 4-keto group in the $C$ ring, and the additional presence of hydroxyl groups at positions $3^{\prime}, 4^{\prime}$ on $B$ ring and hydroxy group in position 7 of the B ring [40]. Such interactions were observed in the compounds identified by Politi et al. (2012) [16] in ethanolic extracts of T. patula.

Considering the interest in use of $T$. patula extracts for preparation of acaricide topical formulations, it became imperative to determine the cytotoxicity. The results presented here indicate that the $\mathrm{Fl}_{\mathrm{EtOH} 70 \%}$ had the highest $\mathrm{IC}_{50}$, however, at the highest concentration tested $(2000 \mu \mathrm{g} / \mathrm{mL})$ was as cytotoxic as the others. On average, up to $250 \mu \mathrm{g} / \mathrm{mL}$, the only extract that showed cytotoxicity index higher than $50 \%$ was $\mathrm{AP}_{\mathrm{EtOH}} 70 \%$, showing $58 \%$ of cell lysis, with the lowest $\mathrm{IC}_{50}$, characterizing it as the most cytotoxic sample. If we imagine the use of a product based on the T. patula extractives as an insecticide, to be sprinkled on the environment, significant results, as those mentioned by Dharmagadda et al. (2005) [41], could be achieved. However, if we develop a topical formulation to use in domestic animals, further studies with other cell strains would be necessary in order to ensure the security of your application.

For centuries, formulations containing flavonoids as the main pharmacological active constituents have been used to treat diseases. Antibacterial activity of flavonoids has been reported in several studies [42]. In the present work, the best results against the filamentous fungi were obtained with the $\mathrm{Fl}_{\mathrm{EtOH} 70 \%}$, probably due to its higher concentration of flavonoids, with MIC values ranging from $195.3 \mu \mathrm{g} / \mathrm{mL}$ to $572.9 \mu \mathrm{g} / \mathrm{mL}$ against $M$. canis and T. mentagrophytes, respectively. The $\mathrm{AP}_{\mathrm{EtOH}} 0 \%$ showed good antifungal activity against T. rubrum (40004), whereas Lima et al. (2009) [43], using methanolic extract of aerial parts of Tagetes mendocina found MIC values greater than $1000 \mu \mathrm{g} / \mathrm{mL}$ against Mycrosporum gypseum, T. rubrum and T. mentagrophytes strains. According to Rios and Recio (2005) [44], the presence of activity is very interesting in the case of concentrations below $100 \mu \mathrm{g} / \mathrm{mL}$ for extracts and $10 \mu \mathrm{g} / \mathrm{mL}$ for isolated compounds.

In addition, the antimicrobial activity of $70 \%$ ethanolic extracts of $T$. patula was evaluated against two strains of $B$. bassiana and two strains of $M$. anisopliae, with the objective of obtaining high MIC values, enabling, in further studies, a possible synergistic action of these samples with fungal suspensions. The pathogenicity of $M$. anisopliae fungus was observed in eggs and larvae of Rhipicephalus microplus [45], which was found high mortality rates. The in vitro action of the fungus $B$. bassiana for eggs of the same species of tick was also evaluated by Bittencourt et al. (1996) [46]. The authors observed that the percentage of hatching observed in the treated groups was lower than that observed in the control group. Garcia et al. (2004) [47] described the events involved in the mechanism of adhesion, penetration and colonization of adult engorged females of $R$. sanguineus by M. anisopliae. Prette et al. (2005) [24] found that $B$. bassiana were pathogenic for eggs, larvae and engorged nymphs of $R$. sanguineus, with higher efficiency pathogenic action as the concentration of spore suspension used to infect the different stages of the life cycle of the tick was increased. The results of our study are very promising, since, with the exception of the $\mathrm{APWF}_{\mathrm{E}-}$ tOH70\% that showed MIC value of $625 \mu \mathrm{g} / \mathrm{mL}$ against $M$. anisopliae (OCF) and B. bassiana (4531), all other extracts had MIC values higher than $1250 \mu \mathrm{g} / \mathrm{mL}$.

\section{Conclusions}

The high antioxidant potential presented by the samples, with percentages of antiradical activity similar to analyzed patterns, may be explained due to the high concentration of total flavonoids present in T. patula, especially in the flowers. No significant results against dermatophytes or against entomopathogenic fungi were obtained. In the second case, the result is interesting from the point of view of seeking a synergy of strains of $B$. bassiana and $M$. anisopliae with compounds of T. patula, in order to intensify the anti-tick potential of both, constituting a first step on this way. The high cytotoxic activity observed for these extractives in assays with murine macrophages suggest the application of products developed from these samples against ticks only on the environment, until further studies would be performed with other cell lines 
especially dermal strains.

\section{Acknowledgments}

We thank to São Paulo Research Foundation (FAPESP) for financial support and University of Campinas (UNICAMP) by the partnership.

\section{Glossary}

Dermatophyte a fungus belonging to the genera Epidermophyton, Microsporum, or Trichophyton with the ability to utilize keratin to infect hair, nail and skin.

Entomopathogenic fungi a fungus able of causing disease or kill insects.

Flavonoids secondary metabolites found in plants, including many different compounds, such as flavonols, flavones, isoflavones, catechins and anthocyanidins, which has antioxidant potential.

Ixodid a tick belonging to the family Ixodidae, also known as hard tick.

Macrophage any mononuclear phagocytic cell arising from monocytic stem cells in the bone marrow.

Minimum inhibitory concentration the smallest concentration of an antibiotic or other product that regularly inhibits growth of a microorganism in vitro

Pearson linear correlation is a measure of the strength of the linear relationship between two variables. It can range from -1 to 1 , indicate by $\rho$ coefficient.

Percolation procedure of extraction of a plant material using a special apparatus through which a solvent is gradually released.

\section{References}

[1] A. Heimerdinger, C.J. Olivo, M.B. Molento, C.A. Agnolin, M.F. Ziech, L.F.B. Scaravelli, et al., Extrato alcoólico de capim-cidreira no controle do Boophilus microplus em bovinos, Rev. Bras. Parasitol. Vet. 15 (1) (2006) 37-39,

[2] R.A. Yunes, R.C. Pedrosa, V. Cechinel Filho, Fármacos e fitoterápicos: a necessidade do desenvolvimento da indústria de fitoterápicos no Brasil, Quim. Nova 24 (1) (2001) 147-152.

[3] C. Romagnoli, D. Mares, M.P. Fasulo, A. Bruni, Antifungal effects of $\alpha$-terthienyl from Tagetes patula on five dermatophytes, Phytother. Res. 8 (1994) 332-336.

[4] D. Mares, B. Tosi, F. Poli, E. Andreotii, C. Romagnoli, Antifungal activity of Tagetes patula extract on some phytopathogenic fungi: ultrastructural evidence on Phytium ultimum, Microbiol. Res. 159 (2004) 295-304.

[5] C. Romagnoli, R. Bruni, E. Andreotti, M.K. Rai, C.B. Viventi, D. Mares, Chemical characterization and antifungal activity of essential oil of capitula from wild Indian Tagetes patula L, Protoplasma 225 (2005) 57-65.

[6] M.L. Tereschuk, M.D. Baigori, L.R. Abdala, Antibacterial activity of Tagetes terniflora, Fitoterapia 74 (2003) 404-406.

[7] M. Rondón, J. Velasco, J. Hernandéz, M. Pecheneda, J. Rojas, A. Morales, et al. Chemical composition and antibacterial activity of the essential oil of Tagetes patula L. (Asteraceae) collected from the Venezuela Andes, Rev. Latinoamer Quím. 34 (2006) 1-3.

[8] N. Dasgupta, S. Ranjan, P. Saha, R. Jain, S. Malhotra, M.A.A.M. Saleh, Antibacterial activity of leaf extract of Mexican marigold (Tagetes erecta) against different gram positive and gram negative bacterial strains, J. Pharm. Res. 5 (8) (2012) 4201-4203.

[9] M.J. Abad, P. Bermejo, P.S. Sanchez, X. Chirigota, L. Carrasco, Antiviral activity of some South American medicinal plants, Phytother. Res. 13 (1999) 142-146,

[10] F.J. Gommers, J. Bakker, Physiological changes induced by plant responses or products, in: G.O. Poinar-Júnior, H.B. Jansson (Eds.), Diseases of Nematodes, Vol. 1, CRC Press Inc, Boca Raton, 1988.

[11] I.T.F. Macedo, C.M.L. Bevilaqua, L.M.B. Oliveira, A.L.F. Camurça-Vasconcelos, S.M. Morais, L.K.A. Machado, et al., In vitro activity of Lantana camara, Alpinic zerumbet, Mentha villosa and Tagetes minuta decoctions on Haemonchus contortus eggs and larvae, Vet. Parasitol. 190 (2012) 504-509.

[12] D. Laurent, L.A. Vilaseca, J.M. Chantraine, C. Ballivian, G. Saavedra, R. Ibanez, Insecticidal activity of essential oils on Triatoma infestans, Phytother. Res. 11
(1997) 285-290

[13] J.M. Chantraine, D. Laurent, C. Ballivan, G. Saavedra, R.V.S. Ibanez, Insecticidal activity of essential oil on Aedes aegypti larvae, Phytother. Res. 12 (5) (1998) 350-354.

[14] S. Faizi, S. Fayyaz, S. Bano, E.Y. Iqbal, Siddiqi H. Lubna, et al., Isolation of nematicidal compounds from Tagetes patula L. yellow flowers: structureactivity relationship studies against cyst nematode Heterodera zeae infective stage larvae, J. Agric. Food Chem. 59 (17) (2011) 9080-9093.

[15] M.V. Garcia, J. Matias, J.C. Barros, D.P. De Lima, R.S. Lopes, R. Andreotti, Chemical identification of Tagetes minuta Linnaeus (Asteraceae) essential oil and its acaricidal effect on ticks, Rev. Bras. Parasitol. Vet. 21 (4) (2012) 405-411.

[16] F.A.S. Politi, G.M.F. Figueira, A.M. Araújo, B.R. Sampieri, M.I. Camargo-Mathias, M.P.J. Szabó, et al., Acaricidal activity of ethanolic extract from aerial parts of Tagetes patula L. (Asteraceae) against larvae and engorged adult females of Rhipicephalus sanguineus (Latreille, 1806), Paras. Vect. 5 (2012) 295-306.

[17] F.A.S. Politi, T.M.S. Moreira, E.R. Rodrigues, G.M. Queiroz, G.M. Figueira, A.H. Januário, et al., Chemical characterization and acaricide potential of essential oil from aerial parts of Tagetes patula L. (Asteraceae) against engorged adult females of Rhipicephalus sanguineus (Latreille, 1806), Parasitol. Res. 112 (6) (2013) 2261-2268.

[18] F.A.S. Politi, G.M. Figueira, M.I. Camargo-Mathias, J.M. Berenger, P. Parola, R.C.L.R. Pietro, Action of ethanolic extract from aerial parts of Tagetes patula L. (Asteraceae) on hatchability and embryogenesis of Rhipicephalus sanguineus eggs (Acari: Ixodidae), Ind. Crop Prod. 67 (2015) 55-61.

[19] P.E. Massera, T. Rodriguez, A.M. Giulietti, Thiophene production in transformed roots cultures of Tagetes filifolia, Biotec. Lett. 20 (6) (1998) 573-577.

[20] H. Bano, S.W. Ahmed, I. Azhar, M.S. Ali, N. Alam, Chemical constituents of Tagetes patula L, Pak. J. Pharm. Sci. 15 (2) (2002) 1-12.

[21] S. Ivancheva, M. Zdravkova, Flavonoids in Tagetes patula, Fitoterapia 64 (1993) $555-558$.

[22] D. Chandler, G. Davidson, J.K. Pell, B.V. Ball, K. Shaw, K.D. Sunderland, Fungal biocontrol of Acari, Biocontrol Sci. Technol. 10 (2000) 357-384.

[23] L.M. Basso, A.C. Monteiro, M.A.A. Belo, V.E. Soares, M.V. Garcia, D.A. Mochi, Controle de larvas de Boophilus microplus por Metarhizium anisopliae em pastagens infestadas artificialmente, Pesq. Agropec. Bras. 40 (6) (2005) 595-600.

[24] N. Prette, A.C. Monteiro, M.V. Garcia, V.E. Soares, Patogenicidade de isolados de Beauveria bassiana para ovos, larvas e ninfas ingurgitadas de Rhipicephalus sanguineus, Cienc Rural 35 (4) (2005) 855-861.

[25] In P. Kaeng, N. Simasatikul, K. Nganvongpanit, M. Thungrabeab (Eds.), Pathogenicity of Beauveria Bassiana to Engorged Female, Eggs and Larvae Cattle Tick (Boophilus Microplus, Canestrini). Proceedings of the International Conference on the Role of Universities in Hands-on Education, Rajamangala University of Technology Lanna, Chiang-Mai, Thailand, 2009 Aug 23-29, pp. $376-381$.

[26] L.A.G. Barci, J.E.M. Almeida, A.H.C. Nogueira, L.O. Zappelini, A.P. Prado, Seleção de isolados do fungo entomopatogênico Beauveria bassiana (Ascomycetes: Clavicipitaceae) para o controle de Rhipicephalus (Boophilus) microplus (Acari: Ixodidae), Rev. Bras. Parasitol. Vet. 18 (1) (2009) 7-13.

[27] X. Jin, D.A. Streett, C.A. Dunlap, M.E. Lyn, Application of hydrophilic-lipophilic balance (HLB) number to optimize a compatible non-ionic surfactant for dried aerial conidia of Beauveria bassiana, Biol. Control 46 (2008) 226-233.

[28] C. Cafarchia, D. Romito, G. Capelli, J. Guillot, D. Otranto, Isolation of Microsporum canis from the coat of pet dogs and cats belonging to owners diagnosed with M. canis tea corporis, Veter. Dermatol. 17 (5) (2006) 327-331.

[29] A. Djeridane, M. Yousfi, B. Nadjemi, D. Boutassouna, P. Stocker, N. Vidal, Antioxidant activity of some Algerian medicinal plants extracts containing phenolic compounds, Food Chem. 97 (2006) 654-660.

[30] S. Bashir, A.H. Gilani, Studies on the antioxidant and analgesic activities of Aztec marigold (Tagetes erecta) flowers, Phytother. Res. 22 (2008) 1692-1694.

[31] National Committee for Clinical Laboratory Standards, Reference Method for Broth Dilution Antifungal Susceptilibity Testing of Filamentous Fungi: Approved Standard M-38A2, NCCLS, Wayne, Pennsylvania, 2008.

[32] S.A. Ahmed, R.M.J. Cogal, J.E. Walsch, A new rapid and simple non-radioactive assay to monitor and determine the proliferation of lymphocytes: an alternative to $\left[{ }^{3} \mathrm{H}\right]$ thymidine incorporation assay, J. Immun. Meth. 170 (1994) $211-222$.

[33] J. O'Brien, I. Wilson, T. Orton, F. Pognan, Investigation of the Alamar Blue (resazurin) fluorescent dye for the assessment of mammalian cell cytotoxicity, Eur. J. Biochem. 267 (2000) 5421-5426.

[34] R.G.R. Woisky, A. Salatino, Analysis of propolis: some parameters and procedures for chemical quality control, J. Apic. Res. 37 (1998) 99-105.

[35] M. Hajimahmoodi, M.R. Oveisi, N. Sadeghi, B. Jannat, M. Hadjibabaie, E. Farahani, et al., Antioxidant properties of peel and pulp hydro extract in tem Persian pomegranate cultivars, Pak. J. Biol. Sci. 11 (12) (2008) 1600-1604.

[36] G.M. Williams, M.J. Iatropoulos, J. Whysner, Safety assessment of butylated hydroxyanisole and butylated hydroxytoluene as antioxidant food additives, J. Food Chem. Toxicol. $37(9-10)(1999)$ 1027-1038.

[37] H. Shi, N. Noguchi, E. Niky, Natural antioxidants, in: J. Pokorny, N. Yanishlieva, M. Gordon (Eds.), Antioxidants in Food Practical Application, CRC, Cambridge, 2001, pp. 147-148.

[38] R.M. Seabra, P.B. Andrade, P. Valentão, E. Fernandes, F. Carvalho, M.L. Bastos, Antioxidant compounds extracted from several plant materials, in: M. Fingerman, R. Nagabhushanam (Eds.), Biomaterials from Aquatic and 
Terrestrial Organisms, Science, Enfield (NH) USA, 2006, pp. 115-174.

[39] W. Li, Y. Gao, J. Zhao, Q. Wang, Phenolic, flavonoid, and lutein ester content and antioxidant activity of 11 cultivars of Chinese Marigold, J. Agric. Food Chem. 55 (21) (2007) 8478-8484.

[40] C.A. Rice-Evans, N.J. Miller, P.G. Bolwell, P.M. Bramley, J.B. Pridham, The relative antioxidant activities of plant-derived polyphenolic flavonoids, Free Radic. Res. 22 (1995) 375-383.

[41] V. Dharmagadda, S. Naik, P. Mittal, P. Vasudevan, Larvicidal activity of Tagetes patula essential oil against three mosquito species, Biores. Technol. 96 (2005) $1235-1240$.

[42] T.P. Cushnie, A.J. Lamb, Antimicrobial activity of flavonoids, Int. J. Antimicrob. Agents 26 (5) (2006) 343-356.

[43] B. Lima, M.B. Agüero, J. Zygadlo, A. Tapia, C. Solis, A.R. Aarias, et al., Antimicrobial activity of extracts, essential oil and metabolites obtained from Tagetes mendocina, J. Chil. Chem. Soc. 54 (2009) 68-72.

44] J.L. Rios, M.C. Recio, Medicinal plants and antimicrobial activity, J. Ethnopharmacol. 100 (2005) 80-84.

[45] V.R.E.P. Bittencourt, C.L. Massard, A.F. Lima, Ação do fungo Metarhizium anisopliae (Metschnikoff, 1879) Sorokin, 1883, em ovos e larvas do carrapato Boophilus microplus (Canestrini, 1887), Rev. Univ. Rural. 16 (1994) 32-38.

[46] V.R.E.P. Bittencourt, S.L.F.S. Peralva, E.C. Viegas, S.B. Alves, Avaliação dos efeitos do contato de Beauveria bassiana (Bals.) Vuill. com ovos e larvas de Boophilus microplus (Canestrini, 1887) (Acari: Ixodidae), Rev. Bras. Parasitol. Vet. 5 (1996) 81-84.

[47] M.V. Garcia, A.C. Monteiro, M.P.J. Szabó, Colonização e lesão em fềmeas ingurgitadas do carrapato Rhipicephalus sanguineus causadas pelo fungo Metarhizium anisopliae, Cienc. Rural. 34 (5) (2004) 1513-1518. 